\title{
Application of QUECHERS Extraction Coupled With GC/MS for Detection of Polycyclic Aromatic Hydrocarbons and Organochloride Pesticides in Lake Water
}

\author{
Magloire A. N. Gbaguidi ${ }^{1}$, Alassane A. K Youssao ${ }^{1}$, Michael K. Saizonou ${ }^{1}$, Romain O. P. Singbo ${ }^{1,3}$, Léonce F. \\ Dovonon $^{1}$, Aimé Zannou ${ }^{1}$, Henri H. Soclo ${ }^{1}$, Laurent Lanceleur ${ }^{2}$, Mathilde Monperus ${ }^{2}$, Olivier Donald ${ }^{2}$, Daouda Mama ${ }^{3}$ \\ ${ }^{1}$ Unité de Recherche en Ecotoxicologie et Etude de Qualité (U.R.E.E.Q)/Laboratoire d'Etude et de Recherche en \\ Chimie Appliquée (LERCA)/Ecole Polytechnique d'Abomey-Calavi (EPAC 01BP2009)/ Université d'Abomey-Calavi \\ (UAC), Cotonou, République du Bénin \\ ${ }^{2}$ Lababoratoire de Chimie Analytique Bioinorganique et Environnement (LCABIE) Institut Pluridisciplinaires de \\ Recherche en Environnement et Matériaux (IPREM) Université de Pau et des Pays de l'Adour (UPPA EM-UMR 52 \\ Adresse: 0 A): 54) Heliopac, République du Bénins \\ ${ }^{3}$ Laboratoire d'Hydrologie Appliquée (LHA)/Faculté des Sciences et Technique (FAST)/Université d'Abomey-Calavi \\ (UAC), Cotonou, République du Bénin
}

Correspondence: Alassane A. K Youssao, Department of Chemical Engineering - Processes, Polytechnic School of Abomey-Calavi, Benin. Email: youssaoalassane@gmail.com

Received: September 20, 2018 Accepted: November 13, 2018 Online Published: November 19, 2018

doi:10.5539/ijc.v10n4p57

URL: https://doi.org/10.5539/ijc.v10n4p57

\begin{abstract}
The extensive development of industries gives birth to many chemicals which brings contaminations towards environment. The present study is to apply QUECHERS extraction coupled with GC/MS for detection of polycyclic aromatic hydrocarbons (PAHs) and organochloride pesticides (OCPs) in Lake Nokoué of Benin Republic. The method was first benchmarked with standard PAHs and OCPs, and limit of detection (2-194 ppb) and limit of quantification (8-645 ppb) were obtained with recovery rate of $91-110 \%$. The method was then applied to the detection of PAHs and OCPs in the lake water, no benzo[a]pyrene, chrysene or pyrene was detected. The main origin of PAH compounds in Nokoué Lagoon are material combustion and fuels for Polycyclic Aromatic hydrocarbons and due to remoteness pollution for organochorid pesticides compounds.
\end{abstract}

Keywords: development, analytical method, research, PAHs, OCPs, QUECHERS GC/MS

\section{Introduction}

Due to diversity of pollutants released and the associated risks, analytic methods to assess the actual extent of damage are still a challenge for the analyst despite the existence of panoply of techniques. To limit exposures to very toxic organic extraction solvents and to optimize the analytical times, multi-residue pretreatment techniques have been developed and are now widely used in research of organic pollutants (Cortés-Aguado et al., 2008; Perret et al., 2004 \& Bogiallia et al., 2004). These techniques include assisted microwave, pressurized fluid (ASE), critical $\mathrm{CO}_{2}$, acetonitrile extractions such as the developed and improved QUECHERS method (Anastassiades et al., 2003, Lehotay et al., 2005 \& Kmellár). et al., 2010). The last method is less expensive, very reliable, effective, fast, reproducible and less toxic. This analytical approach is accompanied by the production of very powerful chromatographs equipped with high-performance sensors such as GC-MS, GC-MS / MS, LC-MS, LC-MS / MS able to separate and detect individual molecules of organic pollutants in a complex mixture resulting from a pretreatment of any environmental matrix (Chamkasem et al., 2013 \& Salem et al., 2016). The choice of natural water samples for this method is based on the waters of Lake Nokoué, a lake belonging to one of the most important hydrographic complexes in West Africa. This ecosystem, under a strong demographic pressure because of its location in urban areas whose consequences of mismanagement of municipal wastes, are characterized by garbage dump along its banks. It is also the receptacle of wastewater and wastes from the city of Cotonou, lacustrine villages of the town-hall of Sô-Ava, the town of Abomey-Calavi on the one hand and surface water such as the Ouémé River draining runoff that has leached cropland in large part of Benin Republic. Thus, these waters carry residues of agricultural inputs. Studies have revealed that the Cotonou Channel and Nokoué Lake ecosystems are heavily polluted by organic material of all kinds, including PAHs, 
PCBs and pesticides (Soclo et al., 2008, Yehouenou et al., 2006a \& b). According to the results of these authors, the concentration levels in PAH of the channel vary between 70 and $722 \mathrm{ng} / \mathrm{g}$ of dry sediments and in OCPs of a few ppb in water, sediments and living organisms. Thus, the environmental matrices of such an environment seem appropriate for the simultaneous research and monitoring of PAHs, OCPs and their derivatives by the multiresidue extraction method QUECHERS and gas chromatography coupled to mass spectrometry in an efficient manner. The objective of the study is to develop and adapt these analytical techniques to the evaluation and monitoring of contamination levels of organic pollutants in the lake.

\section{Material and Methods}

\subsection{Stus}

The surface water samples were collected in Nokoué lake, whose geographical coordinates are: $6^{\circ} 25$ ' 60 "N and $2^{\circ}$ $27^{\prime} 0$ " E and 42 meters altitude. It covers an area of 339 ha.

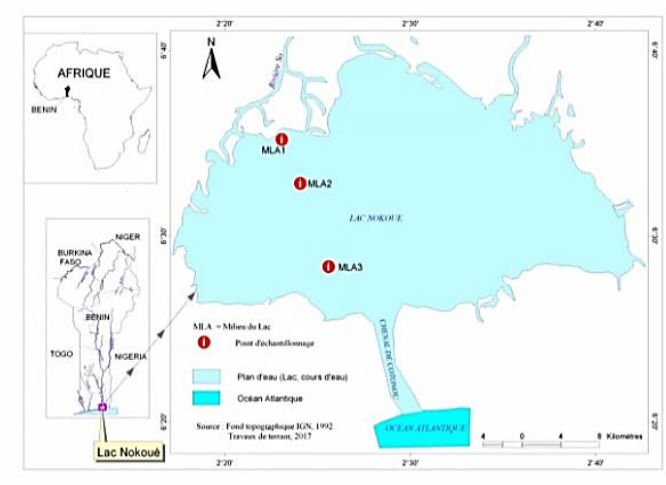

Coordinates of the sampling points

$\begin{array}{lcc}\text { Site names } & \boldsymbol{X} & \boldsymbol{Y} \\ \text { MLA1 } & 2^{\circ} 23^{\prime} 52.0^{\prime \prime} & 6^{\circ} 27^{\prime} 33.9^{\prime \prime} \\ \text { MLA2 } & 2^{\circ} 24^{\prime} 20.0^{\prime \prime} & 6^{\circ} 26^{\prime} 29.1 ” \\ \text { MLA3 } & 2^{\circ} 25^{\prime} 03.1 ” & 6^{\circ} 24^{\prime} 26.5 ”\end{array}$

Figure 1. Map of Nokoué Lake and coordinates of sampling points

The three sampling points are presented on the map of the figure with geographic coordinates (MLA1, MLA2, MLA3). The development, validation of analysis methode and analysis of water samples were carried out at the UFR of Sciences and Techniques of the University Center of Anglet / Université de Pau et des Pays de l'Adour / France.

\subsection{Sampling Campaign}

Before the sampling campaign the glassware was previously depended on washing with soapy water, decontaminated with the sulfochromic mixture, cleaned with bidistilled water and acetonitrile before being packed in aluminum foil. Sampling consisted of water sample extraction from 2-liter amber glass bottles following a transect (Berryman et al., 2004a, Loyo-Rosales et al., 2007, Soclo et al., 2008, Gbaguidi et al. , 2014, Bennie et al., 1997, Cortes-Aguado et al., 2008 \& Gasperi et al., 2009). Before sampling, the bottles are cleaned three times with the sample of water to be taken. In order to stabilize the samples and avoid microbial degradation during transport, they undergo an addition of sulfuric acid (up to $\mathrm{pH}=2$ ). The samples are hermetically sealed by interposing foil between the inside of the lid and the sample. They are then labeled according to the date and place of sampling. The storage and transport of the samples to the laboratories were done in coolers equipped with cold accumulators to keep them at $40{ }^{\circ} \mathrm{C} \pm 5{ }^{\circ} \mathrm{C}$. The campaign was carried out during the period of the small rainy season in southern Benin where the waters of the Ouémé River drain from the north the pollutants mainly of agricultural origin in Lake Nokoué.

\subsection{Validation of the Analytical Method}

\subsubsection{Reagents}

- certified solution of pesticide molecules "Stock TCL Pesticide Mix 2000 ppm in Hexane / Toluene", including: Aldrin, alpha-BHC, beta-BHC, delta-BHC, diene, alpha-endosulfan, beta-endosulfan, sulfate-endosulfan, endrin, endrin-aldehyde, endrin-ketone, gama-BHC, heptachlor, heptachlor-epoxideisomer B, methoxychlor, 4,4'-DDD, 4,4'-DDE, 4,4'-DDT;

- internal standard (EI) of pesticide: atrazine d5;

- certified solution of PAH molecules "Stock EPA 610 PAH 100-2000 ppm in methanol" comprising 16 PAH molecules such as: naphthalene, acenaphthylene, acenaphthene, fluorene, phenanthrene, anthracene, fluoranthene, pyrene, benzo (a) anthracene, chrysene, benzo (b) fluoranrhene, benzo (k) fluoranrhene, benzo (a) pyrene, indeno [1,2,3-cd] pyrene, benzo $[\mathrm{g}, \mathrm{h}, \mathrm{i}]$ perylene, dibenzo $[\mathrm{a}, \mathrm{h}]$ anthracene. For dilutions of PAH solutions, the concentration of Acenaphthene 
was used as a reference. The concentrations of the other PAH molecules were then deduced by calculation compared to their actual concentrations in the concentrated standards;

Six internal standards of PAHs namely: naphthalene-d8, acenaphthene-d10, pyrene-d10, benzo (a) pyrene-d12 and benzo [g, h, i] perylene-d12.

- analytical grade solvents such as acetonitrile, acetic acid, sulfuric acid, acetone and hexane.

All these molecules were purchased from Sigma-Aldrich in France.

2.3.2 Equipment

We use for this work:

- a gas chromatograph (GC) of the Agilent 7890A type

- a mass spectrometer (SM) with an electron impact ionisation source;

- a precision analytical balance of KERN type;

- QUECHERS Agilent Part No: 5982-5121 kits obtained from Agilent Technologies (Massy, France);

- a muffle oven.

\subsubsection{Analytical Conditions}

The GC-MS used is equipped with an Agilent DB5-MS UI column. The carrier gas is high purity helium (99.9995\%) purchased from Air Liquide (France). The flow rate of the carrier gas is $1 \mathrm{~mL} \cdot \mathrm{min}-1$. The temperatures of the injector, the ionization source and the quadrupole are $280{ }^{\circ} \mathrm{C}$., $230{ }^{\circ} \mathrm{C}$. and $150{ }^{\circ} \mathrm{C}$ respectively. The pulsed mode (splitless) was adopted for the injection of the purified extracts and the injected volume is $1 \mu \mathrm{L}$. The oven temperature programming ramp is: initial temperature of $80{ }^{\circ} \mathrm{C}$ for $1 \mathrm{~min}$, then $10{ }^{\circ} \mathrm{C} / \mathrm{min}$ up to $160{ }^{\circ} \mathrm{C}$ and finally $3{ }^{\circ} \mathrm{C} / \mathrm{min}$ up to $300{ }^{\circ} \mathrm{C}$. The temperature of the interface of the mass spectrum is maintained at $300^{\circ} \mathrm{C}$. Ion monitoring mode (SIM) was used for quantitative analysis, while full scan mode was used for qualitative analysis (Ben Salem et al., 2016 \& Chamkasem et al., 2013).

\subsubsection{Validation Criteria}

The validation of the method consisted in evaluating: the retention times, the linearity through the calibration (external and internal), the repeatability and the reproducibility, the limits of detection (LOD) and of quantification (LOQ). To do this, standard certified mixed reference solutions of desired molecules are prepared in the range of $0-1000 \mathrm{ppb}$ and injected. Using the chromatograms, the mass spectra $\mathrm{m} / \mathrm{z}$ are determined as well as the retention times and the corresponding areas. From the different calculated areas and the corresponding concentrations, the external and internal calibration curves are plotted in Excel. The slopes, the coefficients of determination $\mathrm{R}^{2}$ and the ordinates at the origin of the different calibration curves are calculated.

For repeatability, five (05) repetitions of the range of $0-500 \mathrm{ppb}$ were performed in the same day. As for the reproducibility, the injection of the standard solution is made over 5 days for the range $0-500 \mathrm{ppb}$ and the coefficients of variation \% $\mathrm{CV}$ are calculated in each case. So:

$\% \mathrm{CV}=\sigma \mathrm{i} / \chi \mathrm{i} \times 100$ with $\sigma \mathrm{i}$ the standard deviation "SD" and $\chi \mathrm{i}$ the arithmetic mean of the analytical values obtained.

- if $\mathrm{CV}<2 \%$, the measurements are very homogeneous and the experiment is repeatable or reproducible;

- if $2 \%<\mathrm{CV}<30 \%$, the measurements are homogeneous and the repeatability or reproducibility of the experiment is acceptable;

- if CV > 30\%, the measurements are heterogeneous so the experiment is non-repeatable or non-reproducible (Gbaguidi et al., 2011, Kouzayha, 2011 \& Salem et al., 2016).

The limit of detection (LOD) was determined by considering three times the standard deviation of the background noise after ten injections of the reagent blank. While the limit of quantification (LOQ) was determined by considering ten times the standard deviation of background noise after ten injections of reagent blank. The percentages of recovery of the various desired compounds are calculated using the standard solution of the calibration point $100 \mathrm{ppb}$ according to the formula:

$$
\% \mathbf{R}=\frac{\text { calculated concentration-White concentration }}{\text { theoretical concentration }} \mathbf{X 1 0 0}
$$

\subsection{Extraction of Natural Water Samples}

Before analysis of the water samples by GC / MS, they underwent extraction, concentration and purification steps in 
accordance with the QUECHERS methodology. This technique has allowed us to expand the range and number of individual molecules of organic pollutants and related metabolites. For the extraction, $15 \mathrm{~mL}$ of each water sample to be extracted were introduced into $50 \mathrm{~mL}$ flasks to which $15 \mathrm{~mL}$ of acetonitrile $+1 \%$ of HAC (acetic acid) and $100 \mu \mathrm{l}$ of a mixed solution were added. $1 \mathrm{ppm}$ internal standard (extraction of IE) containing naphthalene d8, phenanthrene d10, perylene d12, atrazine $\mathrm{d} 5$ and stirred for a few seconds on vortex. To this mixture is added $6 \mathrm{~g}$ of $\mathrm{MgSO}_{4}+1.5 \mathrm{NaAC}$ (sodium acetate) and stirred manually for 30 seconds. The flasks are centrifuged at $3000 \mathrm{rpm}$ for $2 \mathrm{~min} .8 \mathrm{~mL}$ of each supernatant is collected in $15 \mathrm{~mL}$ glass test tubes for dry evaporation using the Turbovap LV evaporator under a gentle stream of nitrogen. The dry residue was taken up with $500 \mu \mathrm{l}$ of acetonitrile and passed through the purification in order to reach very low detection limits.

\section{Results and Discussion}

\subsection{Determination of Retention Times and Analyte Weights}

The retention times $t_{R}$, the weights $M / Z$ of the analytes and the internal standards used are recorded in Table 1 .

Table 1. Retention times $t_{R}$ and weights of analytes PAHs and pesticides

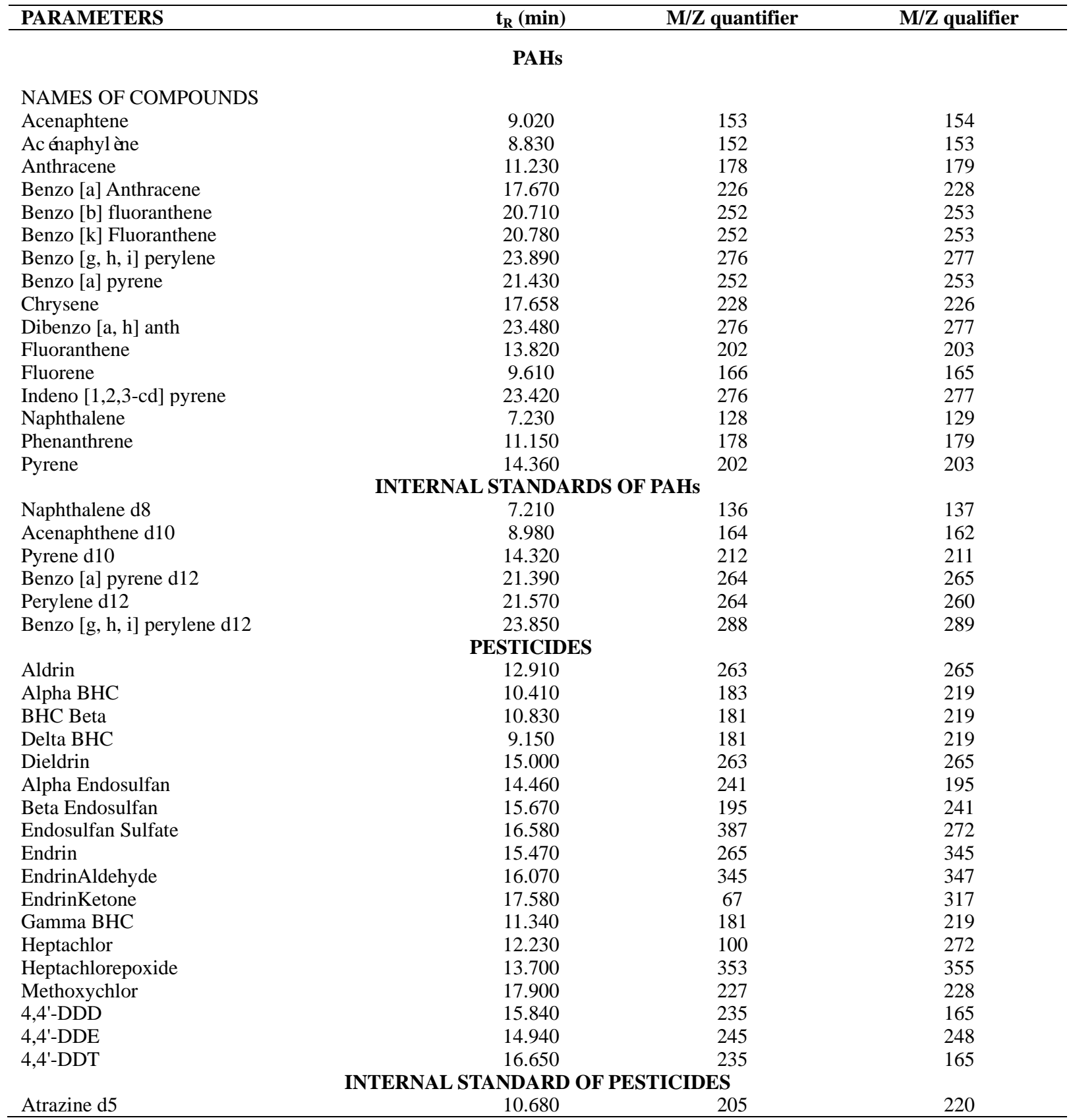


The retention times determined were used to associate with each molecule sought the corresponding EI. Thus, it is noted that the first molecule to be released is Naphthalene $d 8$ whose retention time $t_{R}$ is $7.21 \mathrm{~min}$. It is taken as internal standard for Naphthalene $\left(t_{R}=7.23 \mathrm{~min}\right)$. Acenaphthylene $\left(t_{R}=8.83 \mathrm{~min}\right)$, Acenaphthene $\left(t_{R}=9.020 \mathrm{~min}\right)$, Fluorene $\left(t_{R}\right.$ $=9.61 \mathrm{~min})$ and Anthracene $\left(t_{R}=11.23 \mathrm{~min}\right)$ have for internal standard the Acenaphthene d10 with a retention time of $8.980 \mathrm{~min}$. Benzo $\left[\mathrm{g}, \mathrm{h}, \mathrm{i}\right.$ ] perylene $\mathrm{d} 12$ was removed at $\mathrm{t}_{\mathrm{R}}=23.85 \mathrm{~min}$. It is taken as the internal standard of Benzo [g, $\mathrm{h}, \mathrm{i}]$ perylene. Atrazine d5 taken as internal standard of the pesticides was released at $10.68 \mathrm{~min}$. Pyrene d10, $\mathrm{t}_{\mathrm{R}}=14.32$ min was used as internal standard of the phenanthrene molecules $\left(t_{R}=11.15\right)$, fluoranthene $\left(t_{R}=13.82\right.$ min), pyrene $\left(t_{R}\right.$ $=14.36 \mathrm{~min}$ ), of Benzo (a) Anthracene $\left(t_{R}=17.67 \mathrm{~min}\right)$ and Chrysene $\left(t_{R}=17.66 \mathrm{~min}\right)$. On the other hand, Benzo [a] pyrene $\mathrm{d} 12, \mathrm{t}_{\mathrm{R}}=21.39$ min was used as internal standard of Benzo (b) Fluoranthene $\left(\mathrm{t}_{\mathrm{R}}=20.71\right.$ min), Benzo $(\mathrm{k})$ Fluoranthene $\left(t_{R}=20.78 \mathrm{~min}\right.$ ), and Benzo (a) Pyrene $\left(t_{R}=21.43 \mathrm{~min}\right)$. Finally, P12, $t_{R}=21.57 \mathrm{~min}$, was used as an internal standard for diBenzo $[\mathrm{a}, \mathrm{h}]$ Anthracene $\left(\mathrm{t}_{\mathrm{R}}=23.48 \mathrm{~min}\right)$ and Indeno $[1,2,3-\mathrm{cd}]$ pyrene $\left(\mathrm{t}_{\mathrm{R}}=23.42 \mathrm{~min}\right)$. Our choices are consistent with those of Salem et al. (2016) and Miossec et al., (2018) who worked with the same analytical material as us.

\subsection{External and Internal Calibration}

The slopes, the coefficients of determination $\mathrm{R}^{2}$ and the ordinates at the origin of the calibration curve differences are recorded in Table 2. The coefficients of determination obtained for the external calibration vary from 0.90 to 1 whatever the molecule considered. At the level of the PAHs sought, these coefficients vary from 0.97 to 1 . For the OCPs, $0.90 \leq$ $\mathrm{R}^{2} \leq 1$. For the internal calibration the coefficients of determination vary from 0.99 to 1 for PAHs and from 0.91 to 1 for OCPs. Whatever the external or internal calibration, the values of the coefficient of determination $\mathrm{R}^{2}$ obtained demonstrate that the method has good linearity in the chosen calibration range. In the following, the central (average) and dispersion characteristics of the chromatogram areas obtained during the repeatability and reproducibility tests are calculated and are recorded in Tables 3 and 4.

Table 2. Slopes, coefficients of determination $\mathrm{R}^{2}$ and ordered at the origin of the different calibration curves (external and internal calibration)

\begin{tabular}{|c|c|c|c|c|c|c|}
\hline \multirow{2}{*}{ NAMES OF COMPOUNDS } & \multicolumn{3}{|c|}{ Calibration externe } & \multicolumn{3}{|c|}{ Calibration interne } \\
\hline & Pente & $\mathbf{R}^{2}$ & ord origine & Pente & $\mathbf{R}^{2}$ & ord origine \\
\hline Acenaphtene & 26025.931 & 1 & -320.999 & 0.338 & 0.99 & 0.155 \\
\hline Acénaphylène & 40507.622 & 0.99 & -1623.79 & 0.525 & 1 & 0.379 \\
\hline Anthracene & 77660.874 & 0.97 & -536.587 & 1.012 & 0.99 & -0.03 \\
\hline Benzo [a] Anthracene & 33608.963 & 1 & -180.003 & 0.138 & 0.99 & -0 \\
\hline Benzo [b] fluoranthene & 209462.53 & 0.99 & -536.24 & 1.115 & 1 & 0.033 \\
\hline Benzo [k] Fluoranthene & 69303.2 & 0.99 & -310.791 & 0.368 & 1 & 0.024 \\
\hline Benzo $[\mathrm{g}, \mathrm{h}, \mathrm{i}]$ perylene & 84760.274 & 1 & -552.223 & 0.547 & 1 & -0.01 \\
\hline Benzo [a] pyrene & 101138.28 & 0.99 & -242.498 & 0.538 & 1 & 0.015 \\
\hline Chrysene & 112098.39 & 0.99 & -461.582 & 0.457 & 0.99 & 0.007 \\
\hline Dibenzo $[\mathrm{a}, \mathrm{h}]$ anth & 16102.971 & 1 & -139.912 & 0.105 & 1 & -0.01 \\
\hline Fluoranthene & 132819.95 & 0.99 & -996.356 & 0.539 & 1 & 0.02 \\
\hline Fluorene & 34541.411 & 1 & -155.078 & 0.45 & 0.99 & 0.027 \\
\hline Indeno $[1,2,3-\mathrm{cd}]$ pyrene & 66142.127 & 0.98 & -463.81 & 0.292 & 1 & -0.02 \\
\hline Naphthalene & 33028.887 & 0.99 & -1140.17 & 0.428 & 1 & 0.074 \\
\hline Phenanthrene & 73744.429 & 1 & -61.104 & 0.299 & 0.99 & 0.019 \\
\hline Pyrene & 139799.61 & 0.99 & -560.202 & 0.568 & 1 & 0.01 \\
\hline Aldrin & 23448.552 & 1 & -558.931 & 1.485 & 1 & -0.18 \\
\hline Alpha BHC & 28744.851 & 0.99 & -370.248 & 1.797 & 1 & 0.174 \\
\hline Bhc beta & 29619.104 & 0.99 & -778.547 & 1.867 & 1 & -0.27 \\
\hline Delta BHC & 8513.85 & 1 & -66.186 & 0.532 & 0.99 & 0.103 \\
\hline Dieldrin & 13525.044 & 1 & -366.082 & 0.858 & 1 & -0.14 \\
\hline Alpha endosulfan & 9595.239 & 0.97 & -427.169 & 0.611 & 0.98 & -0.29 \\
\hline Beta endosulfan & 12136.322 & 0.99 & -283.795 & 0.764 & 1 & -0.07 \\
\hline Endosulfan sulfate & 11721.694 & 0.99 & -332.445 & 0.744 & 1 & -0.15 \\
\hline Endrin & 7733.677 & 0.95 & -403.269 & 0.493 & 0.97 & -0.3 \\
\hline Endrinaldehyde & 17354.726 & 0.98 & -698.855 & 1.106 & 1 & -0.44 \\
\hline Endrinketone & 24964.515 & 0.99 & -263.432 & 1.559 & 1 & 0.206 \\
\hline Gamma BHC & 29158.232 & 0.98 & -712.455 & 1.828 & 0.99 & -0.16 \\
\hline Heptachlor & 25465.511 & 0.97 & -1175.05 & 1.625 & 0.99 & -0.82 \\
\hline Heptachlorepoxide & 34749.513 & 0.99 & -979.587 & 2.197 & 1 & -0.41 \\
\hline Methoxychlor & 179834.01 & 0.97 & -8429.74 & 11.476 & 0.98 & -5.95 \\
\hline 4,4'-DDD & 142215.76 & 0.99 & -2935.9 & 8.944 & 1 & -0.41 \\
\hline 4,4'-DDE & 7522.537 & 0.90 & -485.508 & 0.48 & 0.91 & -0.38 \\
\hline $4,4^{\prime}-\mathrm{DDT}$ & 105413.21 & 0.97 & -4875.54 & 6.728 & 0.99 & -3.37 \\
\hline
\end{tabular}

PAHs: Policycliques Aromatic Hydrocarbons; OCPs: Organochlorine Pesticides. 


\subsection{Repeatability}

In the repeatability tests (Table 3) we noticed that at $10 \mathrm{ppb}, 58.54 \%$ of the tests have undetermined \% CV (ND) compared to $32.5 \%$ whose $\% \mathrm{CV}$ have values between 7 and $30 \%$, have. At the $50 \mathrm{ppb}$ concentration level, $70 \%$ of the tests have acceptable repeatability $(5 \leq \% \mathrm{CV} \leq 30)$. On the other hand $80 \%$ of the tests have a $\% \mathrm{CV}$ between 0.35 and 30 at the concentration of $100 \mathrm{ppb}$. More than $92 \%$ of the tests have a \% CV between 4 and 30 at the concentration of $500 \mathrm{ppb}$. According to Salem et al., (2016), these high proportions of ND in low concentrations would be related to a loss of low molecular weight analyte by evaporation during dry extracts resulting in concentration levels under the limit of detection (Miossec et al., 2018). If this hypothesis is true in their case, in our tests the evaporation did not concern that the molecules of low molecular weight. It has affected all molecular weight ranges. To overcome this difficulty, the natural samples to be analyzed are concentrated more than 30 times to get out of the background noise.

Table 3. Repeatability test results

\begin{tabular}{|c|c|c|c|c|c|c|c|c|c|c|c|c|c|c|}
\hline \multirow{2}{*}{ TESTS } & \multicolumn{3}{|c|}{$10 \mathrm{ppb}$} & \multicolumn{4}{|c|}{$50 p p b$} & & \multicolumn{3}{|c|}{$100 \mathrm{ppb}$} & \multicolumn{3}{|c|}{$500 \mathrm{ppb}$} \\
\hline & Mean & $S D$ & $\% \mathrm{CV}$ & & Mean & $S D$ & $\% \mathrm{CV}$ & & Mean & $S D$ & $\% \mathrm{CV}$ & Mean & $S D$ & $\% \mathrm{CV}$ \\
\hline \multicolumn{15}{|c|}{ PAHs } \\
\hline $\begin{array}{l}\text { Names of Compounds } \\
\text { acenaphtene }\end{array}$ & 2141.8 & 619 & 29 & & 7824.8 & 477 & 6 & & 18343.4 & 1824 & 9.94 & 87866.4 & 10688 & 12 \\
\hline Acénaphylène & ND & ND & ND & & 649.25 & 185 & 29 & & 1552.6 & 220 & 14.17 & 6884.8 & 1415 & 21 \\
\hline anthracene & ND & ND & ND & & 160.33 & 92 & 57 & & 494.25 & 143 & 28.97 & 3813.8 & 453 & 12 \\
\hline Benzo [a] Anthracene & 230.0 & 33 & 14 & & 4188.8 & 1072 & 26 & & 6577.25 & 2132 & 32.41 & 39537.4 & 3839 & 10 \\
\hline Benzo [b] fluoranthene & ND & ND & ND & & 4409.33 & 789 & 18 & & 8194 & 347 & 4.24 & 38568.4 & 3862 & 10 \\
\hline Benzo [k] Fluoranthene & ND & ND & ND & & 1927 & 226 & 12 & & 3761.4 & 363 & 9.66 & 18833 & 1721 & 9 \\
\hline Benzo $[\mathrm{g}, \mathrm{h}, \mathrm{i}]$ perylene & 364.0 & 121 & 33 & & 1134.6 & 164 & 14 & & 2454.2 & 517 & 21.05 & 11225.2 & 682 & 6 \\
\hline Benzo [a] pyrene & ND & ND & ND & & 1289 & 147 & 11 & & 2320.4 & 263 & 11.34 & 12411.8 & 1743 & 14 \\
\hline Chrysene & ND & ND & ND & & 634.67 & 427 & 67 & & 2181.33 & 465 & 21.31 & 11408.4 & 1272 & 11 \\
\hline Dibenzo $[\mathrm{a}, \mathrm{h}]$ anth & 397.33 & 121 & 30 & & 2436.2 & 381 & 16 & & 5756.4 & 900 & 15.64 & 27364.2 & 3398 & 12 \\
\hline Fluoranthene & ND & ND & ND & & 683.2 & 137 & 20 & & 1631 & 210 & 12.88 & 7949 & 1305 & 16 \\
\hline Fluorene & ND & ND & ND & & 710 & 158 & 22 & & 2103.5 & 442 & 21.02 & 10757 & 2395 & 22 \\
\hline Indeno $[1,2,3$-cd $]$ pyrene & 1055.7 & 264 & 25 & & 3699.8 & 597 & 16 & & 7704.2 & 913 & 11.85 & 33456.4 & 4715 & 14 \\
\hline Naphthalene & ND & ND & ND & & 882.2 & 292 & 33 & & 1754.8 & 232 & 13.24 & 8837.8 & 1978 & 22 \\
\hline Phenanthrene & 253.3 & 81 & 32 & & 1347 & 256 & 19 & & 2881 & 492 & 17.09 & 14483.6 & 1837 & 13 \\
\hline \multicolumn{15}{|c|}{ INTERNAL STANDARDS OF PAHs } \\
\hline Naphthalene $\mathrm{d} 8$ & 6950.4 & 963 & 14 & & 6739.8 & 858 & 13 & & 7449 & 1452 & 19.49 & 7371.6 & 930 & 13 \\
\hline Acenaphthene d10 & ND & ND & ND & & 552.5 & 138 & 25 & & 606.5 & 2 & 0.35 & 668 & 136 & 20 \\
\hline Pyrene d 10 & 20776.6 & 3434 & 17 & & 22444.4 & 3718 & 17 & & 22592.2 & 4499 & 19.91 & 21604.8 & 3881 & 18 \\
\hline Benzo [a] pyrene d 12 & 9111.2 & 603 & 7 & & 8988.75 & 840 & 9 & & 8342 & 239 & 2.86 & 9422.4 & 410 & 4 \\
\hline Perylene d 12 & 8085.5 & 735 & 9 & & 8353.67 & 645 & 8 & & 8423.25 & 373 & 4.42 & 8182.6 & 863 & 11 \\
\hline $\begin{array}{l}\text { Benzo }[\mathrm{g}, \mathrm{h}, \mathrm{i}] \text { perylene } \\
\mathrm{d} 12\end{array}$ & 7809.75 & 750 & 10 & & 7550.67 & 364 & 5 & & 7768.5 & 673 & 8.66 & 8142.2 & 802 & 10 \\
\hline \multicolumn{15}{|c|}{ PESTICIDES } \\
\hline Aldrin & ND & ND & ND & & 686.67 & 237 & 35 & & 1784.5 & 518 & 29.04 & 11339.8 & 2300 & 20 \\
\hline Alpha BHC & ND & ND & ND & & 1272.8 & 291 & 23 & & 3101.5 & 201 & 6.49 & 13112.4 & 4081 & 31 \\
\hline BHC Beta & 114.0 & 21 & 19 & & 986.4 & 195 & 20 & & 2566.2 & 818 & 31.87 & 12382.4 & 3127 & 25 \\
\hline Delta BHC & ND & ND & ND & & 786.5 & 368 & 47 & & 2093 & 1038 & 49.59 & 5078.66667 & 3348 & 66 \\
\hline Dieldrin & ND & ND & ND & & 297.5 & 18 & 6 & & 1061.67 & 30 & 2.83 & 6573 & 377 & 6 \\
\hline Alpha Endosulfan & ND & ND & ND & & ND & ND & ND & ND & ND & ND & ND & 3860.33333 & 305 & 8 \\
\hline Beta Endosulfan & ND & ND & ND & & 346.33 & 146 & 42 & & 1051.5 & 189 & 17.94 & 5365.2 & 442 & 8 \\
\hline Endosulfan Sulfate & 23.6 & 53 & - & & 398.67 & 143 & 36 & & 758.75 & 203 & 26.72 & 5444.8 & 893 & 16 \\
\hline Endrin & ND & ND & ND & ND & ND & ND & ND & & 283 & 130 & 45.83 & 2610 & 688 & 26 \\
\hline EndrinAldehyde & ND & ND & ND & ND & 236.5 & 175 & 74 & & 834 & 366 & 43.89 & 7035.6 & 816 & 12 \\
\hline EndrinKetone & 340.0 & 191 & 56 & & 1410.25 & 205 & 15 & & 2694 & 248 & 9.20 & 11384 & 997 & 9 \\
\hline gamma BHC & 117.5 & 9 & 8 & & 594.33 & 117 & 20 & & 2248.4 & 618 & 27.49 & 11626.2 & 2207 & 19 \\
\hline heptachlor & ND & ND & ND & & 247.67 & 57 & 23 & & 1114.33 & 534 & 47.91 & 9652.5 & 2823 & 29 \\
\hline HeptachlorEpoxide & ND & ND & ND & & 1166 & 340 & 29 & & 2302.5 & 694 & 30.15 & 15016.2 & 2041 & 14 \\
\hline Methoxychlor & ND & ND & ND & & 2050.67 & 256 & 12 & & 5193.75 & 1126 & 21.68 & 62609.2 & 9638 & 15 \\
\hline 4,4'-DDD & 961.8 & 274 & 29 & & 5940.25 & 360 & 6 & & 11816.5 & 1061 & 8.98 & 64102.8 & 5202 & 8 \\
\hline 4,4'-DDE & ND & ND & ND & & ND & ND & ND & & 117.5 & 21 & 17.45 & 3086.5 & 728 & 24 \\
\hline 4,4'-DDT & ND & ND & ND & & 1300 & 255 & 20 & & 3445.75 & 566 & 16.41 & 40566.4 & 4826 & 12 \\
\hline \multicolumn{15}{|c|}{ INTERNAL STANDARD OF PESTICIDES } \\
\hline Atrazine d5 & 509.33 & 99 & 19 & & 1352.5 & 451 & 33 & & 1630.4 & 183 & 11.23 & 1728.6 & 715 & 41 \\
\hline$\%$ Repeatability & & 32.5 & & & & 70.0 & & & & 80.0 & & & 2.5 & \\
\hline
\end{tabular}

$\mathrm{ND}=$ Not detected, $\mathrm{SD}=$ Standard Deviation, $\% \mathrm{CV}=$ coefficient of variation

\subsection{Reproducibility}

Analysis of the reproducibility data in Table 4 shows that the percentages of validated reproducibility tests vary from 67.7 to $97.5 \%$. The low percentages are found at the concentration of $10 \mathrm{ppb}$. Overall, the reproducibility percentages of the assays are acceptable and are considered satisfactory for validating the method and for use in real-world analyzes. 
Table 4. Reproducibility test results

\begin{tabular}{|c|c|c|c|c|c|c|c|c|c|c|c|c|}
\hline \multirow{2}{*}{ TESTS } & \multicolumn{3}{|c|}{$10 \mathrm{ppb}$} & \multicolumn{3}{|c|}{$50 \mathrm{ppb}$} & \multicolumn{3}{|c|}{$100 \mathrm{ppb}$} & \multicolumn{3}{|c|}{$500 \mathrm{ppb}$} \\
\hline & Mean & $S D$ & $\% \mathrm{CV}$ & Mean & $S D$ & $\% C V$ & Mean & $S D$ & $\% \mathrm{CV}$ & Mean & $S D$ & $\% \mathrm{CV}$ \\
\hline $\begin{array}{l}\text { NAMES } \\
\text { COMPOUNDS }\end{array}$ & $O F$ & \multicolumn{11}{|c|}{ PAHs } \\
\hline Acenaphtene & 722 & 48.477 & 6.714 & 3295.104 & 116.339 & 3.531 & 6615.2 & 4.324 & 0.065 & 29819.92 & 11.573 & 0.039 \\
\hline Acénaphylène & 2154.84 & 53.364 & 2.476 & 7864.936 & 89.092 & 1.133 & 15037.8 & 7381.269 & 49.085 & 87893.76 & 59.412 & 0.068 \\
\hline Anthracene & 20.74 & 1.8105 & 8.730 & 646.572 & 9.661 & 1.494 & 1553.72 & 5.186 & 0.334 & 6885.48 & 1.411 & 0.020 \\
\hline $\begin{array}{l}\text { Benzo [a] } \\
\text { Anthracene }\end{array}$ & 3.2 & 3.962 & 123.823 & 161.416 & 2.517 & 1.560 & 496.844 & 4.845 & 0.975 & 3813.08 & 1.724 & 0.045 \\
\hline $\begin{array}{l}\text { Benzo }[b] \\
\text { Fluoranthene }\end{array}$ & 234.26 & 27.857 & 11.892 & 4196.78 & 19.225 & 0.458 & 6568.6 & 7.403 & 0.113 & 39536.84 & 2.930 & 0.007 \\
\hline $\begin{array}{l}\text { Benzo }[\mathrm{k}] \\
\text { Fluoranthene }\end{array}$ & 77.92 & 4.912 & 6.304 & 4413.55 & 22.774 & 0.516 & 8182.8 & 92.815 & 1.134 & 38570.96 & 5.111 & 0.013 \\
\hline $\begin{array}{l}\text { Benzo }[\mathrm{g}, \mathrm{h}, \mathrm{i}] \\
\text { Perylene }\end{array}$ & 27.36 & 1.585 & 5.794 & 1927.2 & 5.933 & 0.308 & 3763 & 12.042 & 0.320 & 18836.6 & 12.602 & 0.067 \\
\hline Benzo [a] pyrene & 354.18 & 16.812 & 4.747 & 1134.796 & 3.618 & 0.319 & 2448.8 & 9.654 & 0.394 & 11240.08 & 33.682 & 0.300 \\
\hline Chrysene & 2 & 2.549 & 127.475 & 1403.6 & 272.381 & 19.406 & 2317.8 & 5.630 & 0.243 & 12425 & 39.779 & 0.320 \\
\hline Dibenzo $[\mathrm{a}, \mathrm{h}]$ anth & 2.6 & 3.435 & 132.120 & 635.952 & 2.690 & 0.423 & 2185 & 8.689 & 0.398 & 11430.36 & 39.235 & 0.343 \\
\hline Fluoranthene & 392.904 & 8.750 & 2.227 & 2434.24 & 4.625 & 0.190 & 5763.4 & 21.973 & 0.381 & 27361.04 & 14.294 & 0.052 \\
\hline Fluorene & 57.714 & 2.631 & 4.560 & 685.84 & 12.224 & 1.782 & 1630.2 & 3.271 & 0.201 & 7946.8 & 9.680 & 0.122 \\
\hline $\begin{array}{l}\text { Indeno }[1,2,3-\mathrm{Cd}] \\
\text { Pyrene }\end{array}$ & 36.696 & 4.911 & 13.383 & 707.4 & 7.127 & 1.007 & 2100 & 9.165 & 0.436 & 10760.8 & 22.830 & 0.212 \\
\hline Naphthalene & 1066.78 & 59.936 & 5.618 & 3699.96 & 9.111 & 0.246 & 7721.8 & 44.059 & 0.571 & 33472.48 & 31.544 & 0.094 \\
\hline Phenanthrene & 46.3 & 4.872 & 10.524 & 885.8 & 9.445 & 1.066 & 1744 & 31.313 & 1.796 & 8843.8 & 11.498 & 0.130 \\
\hline \multirow[t]{2}{*}{ Pyrene } & 252.306 & 5.784 & 2.293 & 1346 & 3.808 & 0.283 & 2874.6 & 17.473 & 0.608 & 14471.4 & 17.170 & 0.119 \\
\hline & \multicolumn{12}{|c|}{ INTERNAL STANDARDS OF PAHS } \\
\hline Naphthalene d8 & 6965.858 & 49.045 & 0.704 & 6741.8 & 4.817 & 0.071 & 7455.4 & 28.763 & 0.386 & 7365.12 & 39.062 & 0.530 \\
\hline Acenaphthene $\mathrm{d} 10$ & 151.552 & 1.701 & 1.122 & 553.05 & 4.705 & 0.851 & 594.6 & 22.645 & 3.808 & 672.6 & 18.379 & 2.733 \\
\hline Pyrene d 10 & 17090.86 & 8390.001 & 49.091 & 22435.378 & 42.803 & 0.191 & 59211.4 & 93653.195 & 158.167 & 21718.6 & 175.005 & 0.806 \\
\hline Benzo [a] pyrene d 12 & 9012.206 & 95.297 & 1.057 & 8973.2 & 55.585 & 0.619 & 8338.2 & 26.167 & 0.314 & 9423.08 & 4.672 & 0.050 \\
\hline Perylene $\mathrm{d} 12$ & 8038.76 & 105.221 & 1.309 & 8361.372 & 22.474 & 0.269 & 6896.4 & 3414.184 & 49.507 & 8206.92 & 53.771 & 0.655 \\
\hline $\begin{array}{l}\text { Benzo }[g, \quad h, \quad i] \\
\text { Perylene } d 12\end{array}$ & 7892.992 & 124.115 & 1.572 & 7563.754 & 21.947 & 0.290 & 7844 & 216.669 & 2.762 & 8129 & 38.588 & 0.475 \\
\hline & \multicolumn{12}{|c|}{ PESTICIDES } \\
\hline Aldrin & 12 & 5.788 & 48.233 & 680.2 & 12.677 & 1.864 & 1843 & 100.628 & 5.460 & 11381.2 & 89.452 & 0.786 \\
\hline Alpha BHC & 31.344 & 1.171 & 3.735 & 1271.2 & 6.906 & 0.543 & 3107.56 & 22.651 & 0.729 & 13116.2 & 8.843 & 0.067 \\
\hline Bhc beta & 110.2 & 7.629 & 6.923 & 985.32 & 3.670 & 0.372 & 2550.2 & 32.438 & 1.272 & 12409 & 54.397 & 0.438 \\
\hline Delta BHC & 3.8 & 3.564 & 93.782 & 776.6 & 10.899 & 1.403 & 2060 & 117.847 & 5.721 & 5078.93467 & 0.595 & 0.012 \\
\hline Dieldrin & 2.8 & 1.923 & 68.698 & 298.298 & 5.711 & 1.914 & 1074.774 & 82.856 & 7.709 & 6599.6 & 57.134 & 0.866 \\
\hline Alpha endosulfan & 12 & 5.788 & 48.233 & 2 & 2.549 & 1.275 & 13.2 & 4.970 & 37.651 & 3867.6 & 20.744 & 0.536 \\
\hline Beta endosulfan & 3.4 & 3.781 & 111.222 & 348.2 & 7.497 & 2.153 & 1068.2 & 32.011 & 3.00 & 5367.6 & 21.478 & 0.400 \\
\hline Endosulfan sulfate & 22.98 & 1.988 & 8.651 & 397.178 & 12.036 & 3.030 & 752.6 & 10.164 & 1.350 & 5445.2 & 8.585 & 0.158 \\
\hline Endrin & 4 & 3.391 & 84.779 & 112.4 & 5.413 & 4.816 & 273.4 & 23.818 & 8.712 & 2617.4 & 16.994 & 0.649 \\
\hline Endrinaldehyde & 12 & 5.788 & 48.233 & 825.2 & 14.601 & 1.769 & 834 & 0 & 0 & 7047.4 & 30.171 & 0.428 \\
\hline Endrinketone & 2.8 & 2.049 & 73.192 & 1423.2 & 43.234 & 3.038 & 2677.4 & 46.377 & 1.732 & 11376.8 & 84.221 & 0.740 \\
\hline Gamma BHC & 115.7 & 3.493 & 3.019 & 596.6 & 8.649 & 1.450 & 2245 & 11.180 & 0.498 & 11709.8 & 167.512 & 1.430 \\
\hline Heptachlor & 2 & 1.581 & 79.057 & 244.8 & 6.457 & 2.638 & 1106.2 & 15.254 & 1.379 & 9641.4 & 31.604 & 0.328 \\
\hline Heptachlorepoxide & 78.554 & 1.224 & 1.558 & 1158.6 & 42.253 & 3.647 & 2300.6 & 7.537 & 0.328 & 15022 & 13.038 & 0.087 \\
\hline Methoxychlor & 155.472 & 2.794 & 1.797 & 2037.8 & 27.344 & 1.342 & 5133 & 144.477 & 2.815 & 51346.8 & 25179.692 & 49.038 \\
\hline 4,4'-DDD & 950.622 & 34.186 & 3.596 & 4875 & 2389.817 & 49.022 & 11704.4 & 464.696 & 3.970 & 64080 & 88.031 & 0.137 \\
\hline $4,4^{\prime}-\mathrm{DDE}$ & 14.8 & 5.541 & 37.437 & 70.8 & 2.775 & 3.919 & 117.32 & 4.314 & 3.677 & 3095.2 & 71.733 & 2.318 \\
\hline \multirow[t]{2}{*}{ Aldrin } & 112.686 & 5.339 & 4.738 & 1298.4 & 11.929 & 0.919 & 3400.2 & 227.912 & 6.703 & 40565.8 & 6.340 & 0.016 \\
\hline & \multicolumn{12}{|c|}{ INTERNAL STANDARD OF PESTICIDES } \\
\hline Atrazine d5 & 509.616 & 1.954 & 0.383 & 1351.2 & 6.760 & 0.500 & 1636.6 & 12.361 & 0.755 & 1728.2 & 7.6941 & 0.445 \\
\hline$\%$ Reproducibility & & 67.5 & & & 97.5 & & & 92.5 & & & 97.5 & \\
\hline
\end{tabular}

$\mathrm{ND}=$ Not Detected, $\mathrm{SD}=$ Standard Deviation, $\mathrm{CV}=$ Coefficient of Variation, $\mathrm{LOD}=$ Limits of Detection, $\mathrm{LOQ}=$ Quantification 
Table 5 shows the values of the detection and quantification limits and the percentages of recovery

Table 5. Limits of Detection (LOD), Limits Of Quantification (LOQ), and Recovery percentages (\% R)

\begin{tabular}{|c|c|c|c|}
\hline NAMES OF COMPOUND & $\begin{array}{c}\text { Detection Limits (LOD) } \\
\ll \mu g / g »\end{array}$ & $\begin{array}{c}\text { Quantization Limits }(\text { LOQ }) \\
\ll \mu g / g »\end{array}$ & $\begin{array}{c}\text { Recovery Percentage } \\
(\% R)\end{array}$ \\
\hline Acenaphtene & 0.037 & 0.123 & 99 \\
\hline Acénaphylène & 0.120 & 0.401 & 100 \\
\hline Anthracene & 0.021 & 0.069 & 99 \\
\hline Benzo [a] Anthracene & 0.016 & 0.053 & 98 \\
\hline Benzo [b] fluoranthene & 0.012 & 0.039 & 110 \\
\hline Benzo [k] Fluoranthene & 0.013 & 0.045 & 100 \\
\hline Benzo $[\mathrm{g}, \mathrm{h}, \mathrm{i}]$ perylene & 0.019 & 0.065 & 99 \\
\hline Benzo [a] pyrene & 0.017 & 0.058 & 110 \\
\hline Chrysene & 0.012 & 0.041 & 99 \\
\hline Dibenzo $[\mathrm{a}, \mathrm{h}]$ anth & 0.026 & 0.087 & 108 \\
\hline Fluoranthene & 0.022 & 0.075 & 108 \\
\hline Fluorene & 0.013 & 0.045 & 99 \\
\hline Indeno [1,2,3-Cd] Pyrene & 0.021 & 0.070 & 107 \\
\hline Naphthalene & 0.104 & 0.345 & 109 \\
\hline Phenanthrene & 0.002 & 0.008 & 98 \\
\hline Pyrene & 0.012 & 0.040 & 100 \\
\hline Aldrin & 0.071 & 0.238 & 100 \\
\hline Alpha BHC & 0.039 & 0.129 & 109 \\
\hline BHC Beta & 0.079 & 0.263 & 100 \\
\hline Delta BHC & 0.023 & 0.078 & 107 \\
\hline Dieldrin & 0.081 & 0.271 & 108 \\
\hline Alpha Endosulfan & 0.133 & 0.445 & 98 \\
\hline Beta Endosulfan & 0.070 & 0.234 & 100 \\
\hline Endosulfan Sulfate & 0.085 & 0.284 & 100 \\
\hline Endrin & 0.156 & 0.521 & 97 \\
\hline EndrinAldehyde & 0.121 & 0.403 & 106 \\
\hline EndrinKetone & 0.034 & 0.115 & 100 \\
\hline Gamma BHC & 0.073 & 0.244 & 99 \\
\hline Heptachlor & 0.138 & 0.461 & 98 \\
\hline HeptachlorEpoxide & 0.086 & 0.282 & 100 \\
\hline Methoxychlor & 0.141 & 0.468 & 98 \\
\hline 4,4'-DDD & 0.062 & 0.206 & 100 \\
\hline 4,4'-DDE & 0.194 & 0.645 & 91 \\
\hline 4,4'-DDT & 0.139 & 0.462 & 99 \\
\hline
\end{tabular}

An analysis of the data shows that LODs range from $0.002 \mu \mathrm{g} / \mathrm{g}$ to $0.194 \mu \mathrm{g} / \mathrm{g}$. LOQs range from 0.008 to $0.645 \mu \mathrm{g} /$ $\mathrm{g}$. The lowest LOD is obtained for phenanthrene while the highest value is found in 4,4'-DDE. The percentages of recovery vary between 91 and 110 for respectively 4,4'-DDE and Benzo [a] pyrene. Salem et al., (2016) under conditions similar to ours for a multiresidue assay of 16 PAHs, 12 PCBs and 9 OCPs in the sediments, obtained $\mathrm{R}^{2}$ coefficient of determination greater than 0.95 for all the compounds analyzed. The quantification limits (LOQ) found by these authors vary between 0.02 and $9.64 \mathrm{ppb}$. These differences would be related to the state of the columns and detectors used. The column in our tests is relatively old which would be the cause of the limits of detection and quantification too high. Despite these high limits of detection and quantification the method has good linearity, good repeatability and reproducibility for concentrations greater than $10 \mathrm{ppb}$ and can therefore validly be used in real-world for investigations. As such, the internal calibration has been used.

\subsection{Application of the Method to the Analysis of Lake Nokoué Water Samples}

The application of the validated method allowed us to search and to dose these two (02) families of contaminants sought in the waters of Lake Nokoué. The analysis results are shown in Table 6. 
Table 6. Lake Nokoué water analysis results

\begin{tabular}{|c|c|c|c|}
\hline Names of compounds & [MLA1] in ppb & [MLA2] in ppb & [MLA3] in ppb \\
\hline Acenaphtene & 2.492 & 2.894 & 2.503 \\
\hline Acénaphylène & ND & 1.679 & 0.294 \\
\hline Anthracene & 0.046 & 0.115 & 0.131 \\
\hline Benzo [a] Anthracene & 219.31 & 0.009 & 0.017 \\
\hline Benzo [b] fluoranthene & 0.0001 & ND & ND \\
\hline Benzo [k] Fluoranthene & 0.086 & ND & ND \\
\hline Benzo $[\mathrm{g}, \mathrm{h}, \mathrm{i}]$ perylene & 0.008 & 0.0188 & 0.025 \\
\hline Benzo [a] pyrene & ND & ND & ND \\
\hline Chrysene & ND & ND & ND \\
\hline Dibenzo $[\mathrm{a}, \mathrm{h}]$ anth & 0.068 & 0.159 & 0.173 \\
\hline Fluoranthene & 1207.332 & ND & ND \\
\hline Fluorene & 0.677 & 0.865 & 1.23 \\
\hline Indeno [1,2,3-cd] pyrene & 0.037 & 0.041 & 0.037 \\
\hline Naphthalene & 10.225 & 5.796 & 10.516 \\
\hline Phenanthrene & 2.073 & 0.821 & 1.309 \\
\hline Pyrene & ND & ND & ND \\
\hline Aldrin & 0.119 & 0.119 & 0.120 \\
\hline Alpha BHC & 10.209 & ND & ND \\
\hline BHC Beta & 11.371 & 0.15 & 0.149 \\
\hline Delta BHC & 109.280 & ND & ND \\
\hline Dieldrin & 12.269 & 0.167 & 0.17 \\
\hline Alpha Endosulfan & 37.976 & 0.493 & 0.49 \\
\hline Beta Endosulfan & 0.093 & 0.119 & 0.111 \\
\hline Endosulfan Sulfate & 0.206 & 0.206 & 0.206 \\
\hline Endrin & 20.137 & 0.615 & 0.606 \\
\hline EndrinAldehyde & 0.399 & 0.399 & 0.399 \\
\hline EndrinKetone & 45.784 & ND & ND \\
\hline Gamma BHC & 13.291 & 0.099 & 0.094 \\
\hline Heptachlor & 42.940 & 0.533 & 0.518 \\
\hline HeptachlorEpoxide & 0.184 & 0.184 & 0.184 \\
\hline Methoxychlor & 0.518 & 0.521 & 0.5189 \\
\hline 4,4'-DDD & 4.209 & 0.0463 & 0.046 \\
\hline 4,4'-DDE & 19.324 & 0.809 & 0.813 \\
\hline 4,4'-DDT & 38.829 & 0.522 & 0.554 \\
\hline
\end{tabular}

ND: Not Dected

From the analysis of the data in Table 5, we note at the level of PAHs that, out of 16 molecules sought in the lake, three (03) were not detected. Nine (09) out of sixteen PAH molecules were detected at all sites. Contamination levels vary from not determined to $1207.33 \mathrm{ppb}$ on the MLA1 site.

At the level of the OCPs, if on the MLA1 site all the eighteen (18) searched molecules are found, at the MLA sites 2 and 3, three (03) molecules were not detected. These are Delta BHC, EndrineKetone and Alpha BHC. So a total of 15 molecules out of 18 OCPs were detected and quantified at all sites. That is a percentage of $83 \%$ of OCPs. The origin of PAH compounds in Nokoué Lagoon are material combustion and fuels for polycyclic aromatic hydrocarbons and due to remoteness pollution for organochloride pesticide compounds (Soclo, 2008; Yehouenou, 2006a \& b).

\section{Conclusion}

Whatever the external or internal calibration, the values of the coefficient of determination $\mathrm{R}^{2}$ obtained are between 0.98 and 1. These values demonstrate that the method has good linearity in the chosen calibration range. For the repeatability the validation percentages vary from 32.5 to $92 \%$. The low percentages are the repeatability tests for the $10 \mathrm{ppb}$ concentration. This state of affairs would be related to a loss of analyte during the dry extracts. Overall, the reproducibility percentages of the assays are acceptable and are considered satisfactory for validating the method and for use in real-world analyses. For all the molecules sought, the percentage of recovery varies between 91 and $110 \%$ corresponding respectively to Benzo [b] fluoranthene and Benzo [a] pyrene. 


\section{References}

Anastassiades, M., Lehotay, S., Stajnbaher, D., \& Schenck, F. (2003). Fast and easy multiresidue method employing acetonitrile extraction/partitioning and "dispersive solid-phase extraction for the determination of pesticide residues in produce. Journal of AOAC International, 86(2), 412-431.

Ben Salem, F., Ben Said, O., Duran, R., \& Monperrus, M. (2016). Validation of an Adapted QuEChERS Method for the Simultaneous Analysis of Polycyclic Aromatic Hydrocarbons, Polychlorinated Biphenyls and Organochlorine Pesticides in Sediment by Gas Chromatography-Mass Spectrometry. Bulletin of Environmental Contamination and Toxicology - Springer. https://doi.org/10.1007/s00128-016-1770-2

Bennie, A. T. P., Strydom, M., \& Very, H. S. (1997). Use of Computer Models for Agricultural Water Management on Ecotype Level. Water Research Commission Report 625/1/97. Pretoria. 250.

Berryman, D., Houde, F., DeBlois, C. S., \& O'Shea, M. (2004b). Nonylphenolic compounds in drinking and surface waters downstream of treated textile and pulp and paper effluents: a survey and preliminary assessment of their potential effects on public health and aquatic life. Chemosphere, 56(3), 247-255. https://doi.org/10.1016/j.chemosphere.2004.02.030

Berryman, D., Houde, F., DeBlois, C., \& O'Shea, M. (2004a). Nonylphenolic compounds in drinking and surface waters downstream of treated textile and pulp and paper effluents: a survey and preliminary assessment of their potential effects on public health and aquatic life. Chemosphere, 56(3), 247-255. https://doi.org/10.1016/j.chemosphere.2004.02.030

Bogialli, S., Curini, R., Di Corcia, A., Laganà, A., Nazzari, M., \& Tonci, M. (2004). Simple and rapid assay for analyzing residues of carbamate insecticides in bovine milk: hot water extraction followed by liquid chromatography-mass spectrometry. Journal of Chromatography A, 1054, 351-357. https://doi.org/10.1016/j.chroma.2004.04.014

Chamkasem, N., Ollis, L. W., Harmon, T., Lee, S., \& Mercer, G. (2013). Analysis of 136 Pesticides in Avocado Using a Modified QuEChERS Method with LC-MS/MS and GC-MS/MS. J. Agric. Food Chemistry, 61(10), $2315-2329$. https://doi.org/10.1021/jf304191c

Cortes-Aguado, S., Sanchez-Morito, N., Arrebola, F. J., Frenich, A. G., \& Vidal, J. L. M. (2008). Fast screening of pesticide residues in fruit juice by solid-phase microextraction and gas chromatography-mass spectrometry. Food Chemistry, 107, 1314-1325. https://doi.org/10.1016/j.foodchem.2007.09.033

Gasperi, J., Garnaud, S., Rocher, V., \& Moilleron, R. (2009). Priority pollutants in surface waters and settleable particles within a densely urbanized area: case study of Paris (France). Science of the Total Environment - Journal - Elsevier. 407, 2900-2908. https://doi.org/10.1016/j.scitotenv.2009.01.024

Gbaguidi, A. N. M, Dovonon, L. F., Youssao, A., Saizonou, M., Djibril, R., Mohamed, Y. I., ... \& Fayomi, B. (2014). Search of Organochlorine Pesticide Residues (Pocs) in Bodies of Water in Cotton- Growing Area of Benin by GC-ECD. Pak. Journal of Chemistry, 4(2), 49-61, ISSN (Print): 2220-2625 ISSN (Online): 2222-307X. https://doi.org/10.15228/2014.v04.i02.p01

Gbaguidi, M. A. N., Soclo, H. H., Issa, Y. M., Fayomi, B., Dognon, R., Agagbe, A., ... Sanni, A. (2011). Evaluation quantitative des résidus de pyréthrinoïdes, d'aminophosphate et de triazines en zones de production de coton au Bénin par la méthode ELISA en phase liquide: cas des eaux de la rivière Agbado. International Journal of Biological and Chemical Sciences, 5(4), 1476-1490, August 2011. ISSN 1991-8631. https://doi.org/10.4314/ijbcs.v5i4.14

Kouzayha, A. (2011). Développement des méthodes analytiques pour la détection et la quantification de traces des HAP et de pesticides dans l'eau. Application de la méthode à l'évaluation de la qualité des eaux libanaises. Thèse de Doctorat de l'Université de bordeaux 1. 233.

Lehotay, S. J., De Kok, A., Hiemstra, M., \& Van Bodegraven, P. (2005). Validation of a Fast and Easy Method for the Determination of Residues from 229 Pesticides in Fruits and Vegetables Using Gas and Liquid Chromatography and Mass Spectrometric Detection. Journal of AOAC International, 88(2), 595.

Loyo-Rosales, J. E., Rice, C. P., \& Torrents, A. (2007a). Fate of octyl- and nonylphenol ethoxylates and some carboxylated derivatives in three American wastewater treatment plants. Environmental Science \& Technology, 41, 6815-6821. https://doi.org/10.1021/es070713i

Loyo-Rosales, J. E., Rice, C. P., \& Torrents, A. (2007b). Octyl and nonylphenol ethoxylates and carboxylates in wastewater and sediments by liquid chromatography/ tandem mass spectrometry. Chemosphere, 68, $2118-2127$. 
https://doi.org/10.1016/j.chemosphere.2007.02.002

Perret, D., Gentili, A., Marchese, S., Sergi, M., \& D’Ascenzo, G. (2004). Residues and trace elements. Validation of a Method for the Determination of Multiclass Pesticide Residues in Fruit Juices by Liquid Chromatography/ Tandem Mass Spectrometry after Extraction by Matrix Solid-Phase Dispersion. Journal of AOAC international, 85(3), 724-730.

Soclo, H. H., Budzinski, H., Garrigues, P., \& Matsuzawa, S. (2008). Biota accumulation of Polycyclic Aromatic Hydrocarbons in Benin Coastal Waters. Polycyclic Aromatic Compounds, 28, 112-127. https://doi.org/10.1080/10406630801940530

Yehouenou, E. P. A., Lalèyè, P., Boko, M., Van Gestel, C. A. M, Ahissou, H., Akpona, S., ... Van Straalen, N. M. (2006a). Contamination of organochlorine pesticide residues in fish of the Ouémé River catchment in the Republic of Benin. Environment International, 32, 594-599, https://doi.org/10.1016/j.envint.2006.01.003

Yehouenou, E. P. A., Michel, B., Cornelis, A. V. G., Hyacinth A., Philippe, L., Simon, A., Bert, H., Kees, V., \& Nico, S. M. V. S. (2006b). Organochlorine and organophosphorous pesticide residues in the Ouémé River catchment in the Republic of Benin. Environment International, 32, 616-623. https://doi.org/10.1016/j.envint.2006.01.007

\section{Copyrights}

Copyright for this article is retained by the author(s), with first publication rights granted to the journal.

This is an open-access article distributed under the terms and conditions of the Creative Commons Attribution license (http://creativecommons.org/licenses/by/4.0/). 